\title{
The Comparison and Analysis of Technology of Electric Power Information
}

\author{
Zheng Zhu, Qingfen Liao, Jun Jia, Xiangyu Han, Jun Wang, Yangfan Zhang \\ College of Electrical Engineering Wuhan University, Wuhan, Hubei Province, China
}

\begin{abstract}
With the continuous development of the Power market and the power of information technology, communication networks become increasingly complex and the number communication services is rapidly growing, the study of power of information technology become more important, this paper analysis the different communication needs of Power communication and study the characteristics and the requirements in various communication network.
\end{abstract}

KEYWORD: Electric Power information; Power communication; fibre-optical

\section{INTRODUCTION TO THE ELECTRIC POWER INFORMATION}

\subsection{The structure of electric power information}

The electric power industry production process include power industry planning, design, construction, power generation, transmission, distribution, electric power dispatching, power marketing, materials and management and so on.
With the development of power system, automation degree deepens unceasingly. The information demand of power system continuously improve, and information demand rate is accelerating. Current power system has been formed to provide the information exchange between various departments network platform in the elctric generation, substation, transmission, distribution, electricity and control departments, as shown in fig. 1

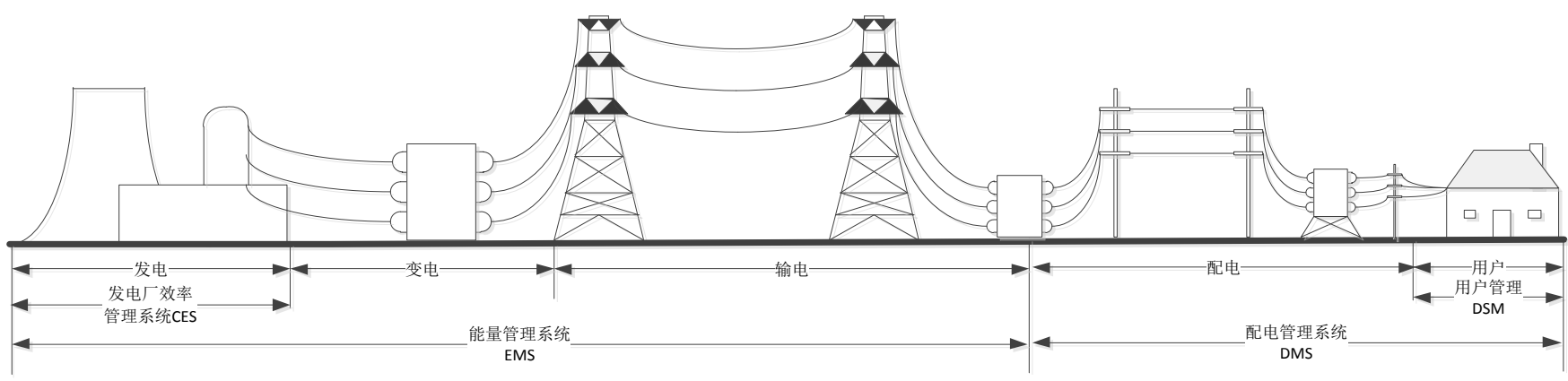

Fig.1 the power generation, transmission, substation, distribution, electricityand control in power system

\subsection{The classify of information in Electric system}

Electric power information needed for power system can be divided into control class of real-time information for production, maintenance, management of quasi real time information and the sale of electricity purchase information[1]. Production control and the class of real-time information refers to the maintenance of the realtime operation of power system information, which transfer less information and real-time. Power system control information include the power system security and stability control signal, preventing voltage collapse control signal and so on. In order to ensure the normal operation of the power, the delay requirement is less than $20 \mathrm{~ms}$ in such information transmission.

The transmission cycle of maintence-management information which the power grid control center obey to the substation or power plant is so long, and the accuracy requirement is second level.

When a disturbance occurred, the wide area measurement system WAMS acquired electrical phasor value and system control center, and the transmission time is less than $20 \mathrm{~ms}$.

The substation transfers bus voltage, current and other information periodicly. Transmission cycle is the second level, and the information transmission time can be equal to or greater than $1 \mathrm{~s}$.

The safety information of electric equipment in substation such as transformer, isolating switch and 
lightning arrester, should response rapidly in the power grid accident cases. Such as state monitoring information, fire protection and security in substation and others. The time that information reaches the control center is less than 2 s.

\subsection{Power system dispatching communication structure}

Between the dispatch center and substation mainly through the telemetry, remote control, remote adjustment, such as the exchange of information, load frequency control voltage control information, and stability control information, cutting load information, synchronized phasor measurement information, consumption information, protection and monitoring information, bidding information and audio, video streaming, as shown in Fig.2. $[3,5,6]$

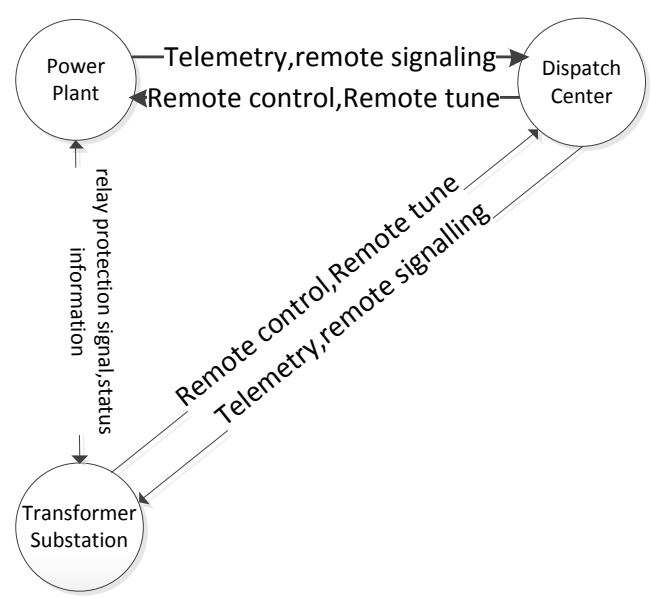

Fig.2 The communication structure of control center and power plant, substation

\subsubsection{The communication structure of distribution station automation}

The architecture of the integrated automation system of substation according to the design thinking can be divided into centralized, distributed and hierarchical distributed[3]

The communication of modern substation adopts the hierarchical structure; the overall structure is divided into the device layer, interlayer and substation layer.

In early stage, RS232/RS485 was used in internal communication of substation automation system. Communication equipments are uncomplicated and low cost, but they are low speed and low efficiency which can only be used in substation in miniature. In the system of large transformer substation, the field bus technology is always been used, for the simple interface, higher speed than traditional RS485, and high transmission reliability. The two common bus in China are CAN and LONWORKS. LAN is the system which connects small and micro computers with peripheral equipment by communication lines, and obey the network communication protocol to communicate. In this system, the computer can work independently, and can exchange data as shown in the table 1 .

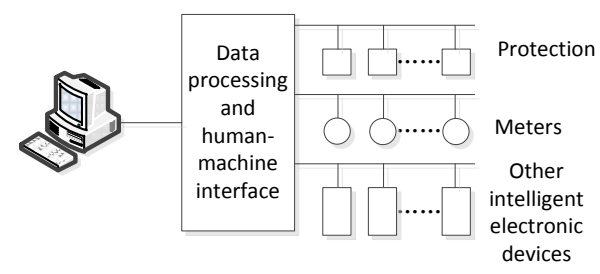

Centralized structure
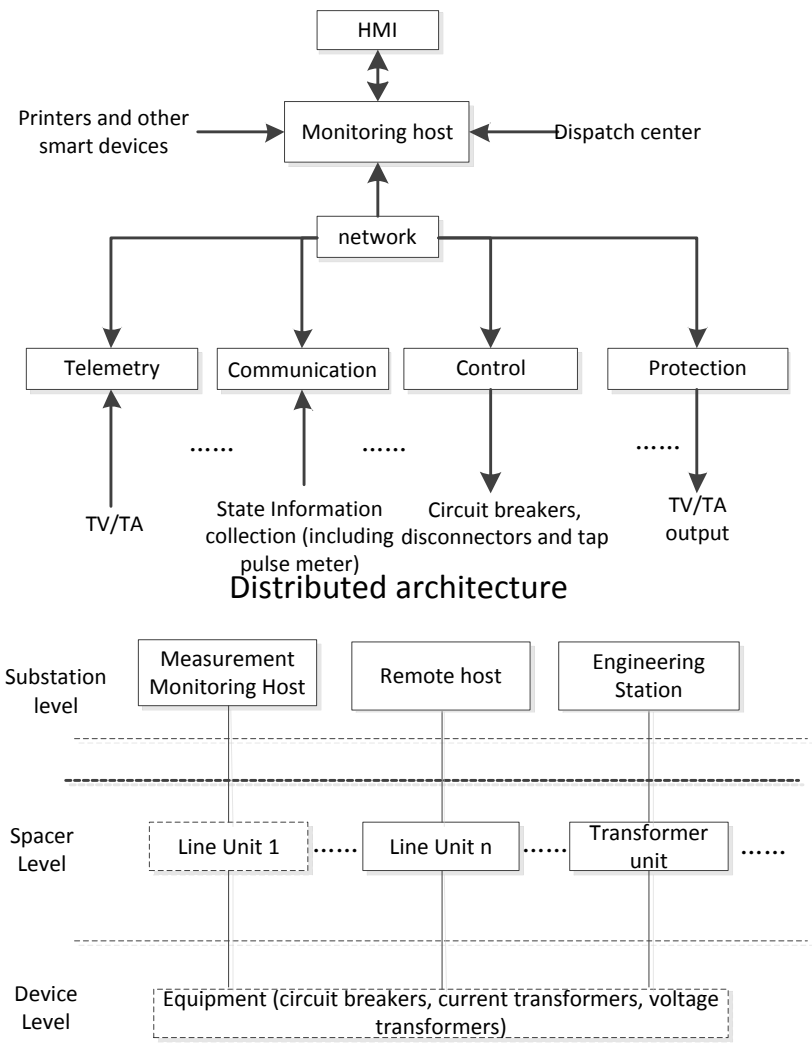

Level structure

Fig. 3 Substation communication structure

Table 1 Communication methods and characteristics of substation automation system

\begin{tabular}{|c|c|c|}
\hline $\begin{array}{c}\text { Communication } \\
\text { mode }\end{array}$ & Characteristic & $\begin{array}{l}\text { Bit error } \\
\text { rate }\end{array}$ \\
\hline $\begin{array}{l}\text { Based on } \\
\text { RS-485 }\end{array}$ & $\begin{array}{l}\text { Large amount of information in } \\
\text { transmission, can be connected } \\
\text { to a network, few nodes, non } \\
\text { equal node, high transmission } \\
\text { rate (representative value } \\
921 \mathrm{kbit} / \mathrm{s}) \text {, real-time differential }\end{array}$ & $10 \mathrm{e}-9$ \\
\hline $\begin{array}{l}\text { Based on } \\
\text { fieldbus } \\
\text { technology }\end{array}$ & $\begin{array}{l}\text { Large amount of information in } \\
\text { transmission, more nodes, equal } \\
\text { node structure, high information } \\
\text { transmission rate(The maximum } \\
\text { rate of communication in CAN } \\
\text { net1Mbit/s), real-time }\end{array}$ & $10 e-6$ \\
\hline $\begin{array}{c}\text { Based on } \\
\text { Ethernet } \\
\text { Technology }\end{array}$ & $\begin{array}{l}\text { Large amount of information in } \\
\text { transmission, The network } \\
\text { connection, Lots of nodes, equal } \\
\text { node structure, extremely speed } \\
\text { in information transmission } \\
(100 \mathrm{Mbit} / \mathrm{s}) \text {, real-time }\end{array}$ & $10 \mathrm{e}-10$ \\
\hline
\end{tabular}




\subsubsection{Communication between substation with control center}

Communication in the substation and the control center is mainly composed of a host computer or communication management machine implementation of telecontrol function, and transmit the analog, power, status information, SOE and so on which substation need tomeasure to the contol center, and receive data and control command from the superior dispatching. Such as switch operation command issued by the receiving dispatching, modifying and protecting constant value online, Summon the real-time operation parameter, etc.

\subsubsection{The communication in dispatching control center}

Dispatch of Electric in our country is divided into nation, network, province, locality and county level.

Table 2 The dispatch center of electric power communication and information flow

\begin{tabular}{|c|c|c|c|}
\hline Classification & Power Application & Content & Information streams \\
\hline \multirow{10}{*}{$\begin{array}{l}\text { Power System } \\
\text { Operation }\end{array}$} & Dispatch Phone & Dispatch and load switching operation & All sites \\
\hline & Video Conferencing & Audio and video data streams & \multirow{3}{*}{$\begin{array}{l}\text { Between the control } \\
\text { center }\end{array}$} \\
\hline & Conference call & Working arrangements & \\
\hline & $\begin{array}{l}\text { Remote communication between } \\
\text { the control center }\end{array}$ & $\begin{array}{l}\text { Measurement information, weather information, } \\
\text { running, transmission line load, load / generation } \\
\text { statements }\end{array}$ & \\
\hline & \begin{tabular}{|l|} 
SCADA/ EMS/ AGC, WAMS, \\
Stability control system, Voltage \\
control system, emergency load \\
shedding systems, electricity billing \\
systems, fault management systems, \\
power generation quotation system, \\
remote simulation training system \\
\end{tabular} & $\begin{array}{l}\text { Telemetry, remote signaling, Remote control, Remote } \\
\text { tune, Load frequency control information, voltage } \\
\text { control information, stability control information, } \\
\text { load shedding information, synchronized phasor } \\
\text { measurement information, power information, the } \\
\text { protection of monitoring information, generating } \\
\text { pricing information, audio, video streaming }\end{array}$ & $\begin{array}{l}\text { Control Center - a } \\
\text { large power plant / } \\
\text { substation }\end{array}$ \\
\hline & SCADA & $\begin{array}{l}\text { Telemetry, remote signaling, Remote control, Remote } \\
\text { tune, Protection monitoring information }\end{array}$ & $\begin{array}{l}\text { Control Center - } \\
\text { small power plants / } \\
\text { unmanned substation }\end{array}$ \\
\hline & DAS/DMS & $\begin{array}{l}\text { Telemetry, remote signaling, Remote control, Remote } \\
\text { tune }\end{array}$ & $\begin{array}{l}\text { Control Center - } \\
\text { distribution } \\
\text { substations } \\
\end{array}$ \\
\hline & \begin{tabular}{|l|} 
Video Conferencing \\
\end{tabular} & Audio and video data streams & Control Center - \\
\hline & \begin{tabular}{|l} 
Application Service System \\
\end{tabular} & Real-time operational status & \\
\hline & Application Service System & Real-time operational status & $\begin{array}{l}\text { Control Center - } \\
\text { Plant / Customer }\end{array}$ \\
\hline \multirow{4}{*}{$\begin{array}{l}\text { Device } \\
\text { Management }\end{array}$} & Administrative Phone & Personal Phone & All sites \\
\hline & Substation remote video monitoring & Video surveillance information & $\begin{array}{l}\text { Control Center- } \\
\text { unmanned substation }\end{array}$ \\
\hline & Network management system & The information transmission apparatus & \multirow{2}{*}{$\begin{array}{l}\text { Control Center - } \\
\text { Substation }\end{array}$} \\
\hline & $\begin{array}{l}\text { Asset management system, device } \\
\text { diagnostics / maintenance system }\end{array}$ & Equipment maintenance, equipment diagnostics & \\
\hline Administration & $\begin{array}{l}\text { Information management systems, } \\
\text { office automation systems, etc. }\end{array}$ & Data files, text, images, faxes, email, etc. & All sites \\
\hline
\end{tabular}

\section{THE PURPOSE OF GETTING POWER INFORMATION}

Acquiring power information ensures the communication security. Electric power communication network transmit real-time operation control and production management information to electric network.

As a support grid infrastructure, communication system and power grid safety and stability control system, power grid dispatching automation system has become an important part of modern grid survival.

\section{THE METHODS TO GET POWER INFORMATION AND THEIR FEATURE}

Electric power information consists of the real-time and non real time information. The main topic is the real time information collection of each power plant, substation of various characterization of power system in running state. It also accepts the control command, and perform the appropriate operation. For non-real time information can be obtained through the related database and data query.

\section{THE NETWORK AND COMMUNICATION TECHNOLOGY ABOUT POWER INFORMATION}

\subsection{The introduction of the network in electric power information}

Platform of power information network can be divided into two categories: One is the power 
production control, such as The data collection and monitoring system(SCADA), distributed control system (DCS), distribution management system (DMS), energy management system(EMS); two is the electric power enterprise management, such as management information system (MIS), enterprise resource planning (ERP), enterprise asset management (EAM), automatic mapping / equipment management / geographic information system (AM/FM/GIS) electric power marketing system,etc. [7,8]

\subsubsection{The data collection and monitoring system of SCADA (Supervisory Control And Data Acquisition)}

SCADA is the foundation and core in power grid dispatching automation system, which is responsible for the collection and processing of the power system real-time and non real time data. The SCADA system consists of the real-time data acquisition, data communication, SCADA system supporting platform, front-end subsystem, the backstage subsystem, etc

\subsubsection{Wide Area Measurement system of WAMS (Wide Area Measurement System)}

The wide area measurement system (WAMS) of the PMU device with GPS as a sampling reference, voltage synchronous acquisition unit and line network, current and important protection switch signal; And calculate the voltage and current pastors, frequency and frequency rate of change, the unit and the line power, the generator potential (angle) and according to the unit key phase signal power angle measurement unit; at the same time, it can also provide the transient record disturbances triggered.

\subsubsection{Energy measurement system of TMR(Tele Meter Reading System)}

The electric energy metering system is the automated tool which the administrative department of electric power management used to electricity metering and settlement, power analysis, statistical loss, energy loss and formulate purchase electricity in power market conditions, provide system optimization based data. Electric energy acquisition and billing automation system and SCADA/ EMS, MIS and etc, will constitute the production of electrical energy, supply sales management tools and improve the level of automation of power grid operation and management [4].

\section{SUMMARIZE}

The power of information technology is an important part of power system. It is the use of wire, radio, light or other electromagnetic system on power system operation, management and other activities in the needs of the various symbols, text, image, sound signal, or any kind of information transmission and exchange, so as to meet the special requirements of communication system of power system.

The power of information technology in the electric power industry, mainly relates to the power substation, transmission, distribution, use between electricity and scheduling and so on each link and each link of power equipment operation and dispatching command transmission and security. All levels of substation and power plant using information technology can realize automatic control of production process and receiving station of remote control commands and feedback of remote department. Early power system in our country mainly adopts the power line carrier, overhead line or cable and other means of communication. $\mathrm{n}$ twentieth Century 60 time begin by microwave, ultra high frequency coaxial cable, multi carrier and other means of communication . 80th in the digital microwave, satellite communications, optical fiber communications, program-controlled exchange and other modern communication technologies have been introduced and widely used. The late 90's electric power communication optical fiber cable technology is widely used in electric power communication network, also obtained great development.

\section{REFERENCES}

[1] XIN Jian-bo and DUAN Xian-zhong, "A study of information requirements classification of power system and needs to communication network," Relay, Vol.32, No.21, 2004, pp.21-25.

[2] Yin Chuanye, "The Application Research of Information Security Strategy in Electric Power Information System," Master's Thesis, Huazhong University of Science and Technology, Wuhan, 2006.

[3] SHAN Li-hua, "Distribution load Monitoring System Based on GPRS, Master's Thesis, North China Electric Power University, Beijing, 2008.

[4] ZHOU Zhi-quan, "Analysis on the Functional Requirements for Automatic System of Energy Acquisition and Billing," Zhejiang Electric Power, 2001, pp.14-16, 52.

[5] Yin Chuanye, "The Application Research of Information Security Strategy in Electric Power Information System," Master's Thesis, Huazhong University of Science and Technology, Wuhan, 2006.

[6] SHAN Li-hua, "Distribution load Monitoring System Based on GPRS, Master's Thesis, North China Electric Power University, Beijing, 2008.

[7] He Yixuan, "The Research of Multi-Source Information Management System of EMS Based on Data Stream Techniques," Master's Thesis, Huazhong University of Science and Technology, Wuhan, 2007.

[8] ZHOU Zhi-quan, "Analysis on the Functional Requirements for Automatic System of Energy Acquisition and Billing," Zhejiang Electric Power, 2001, pp.14-16, 52.

[9] Cui Yuan and Cheng Lin, "Implementation of Remote Real-Time Supervisory Control With ATM Networks," Automation of Electric Power Systems, Vol.26, No.14, 2002, pp.7-11. 